\title{
The Relation between Auditor Switching and Self-fulfilling Prophecy Effect: The Bivariate Probit Model
}

\author{
Yueh-Ju Lin \\ Dept. of Accounting, Kainan University, Taiwan \\ E-mail: judylin@mail.knu.edu.tw
}

Received: April 23, 2014 Accepted: June 12, $2014 \quad$ Published: June 12, 2014

doi:10.5296/ajfa.v6i1.5518ＵRL: http://dx.doi.org/10.5296/ajfa.v6i1.5518

\begin{abstract}
This study investigates the adverse effects of auditor initial going-concern qualified opinion (IGCQ) on the stock and audit market employing the bivariate probit model on Taiwanese public firms. Results show that (1) unobservable interference factors may be responsible for the adverse market effects, (2) interaction exists between the stock and audit markets, (3) the probability of auditor switching is higher if the client is delisted from the market or influenced endogenously, (4) the self-fulfilling prophecy effect is not supported in the Taiwanese stock market; (5) one year after an IGCQ is issued, the client is more likely to switch auditors.
\end{abstract}

Keywords: Going-concern, Self-fulfilling prophecy effect, Auditor switching, Bivariate probit model, Audit and Stock market interaction

JEL Classification: G33, G34, M41, M42 


\section{Introduction}

The stock and audit markets are both in the same open economic environment. Complicated causes or reciprocal effects may influence their interests mutually. Therefore, understanding a market's characteristics and its interaction with others is necessary to discuss market organization behaviors. Audited financial information influences external related parties' financial and credit decisions (Minnis, 2011; Smolarski et al., 2011). Stock prices of public firms will be affected if auditors air opinions of their going-concern uncertainties, or, worse, if they are delisted from the stock market. Generally, the audit market is decided by its demand and supply. However, an auditor switching may occur due to negative audit opinions issued or substantial operational changes of business. Therefore, an inseparable relation exists between stock and audit market when any changes incur to the public firms.

The issuance of initial going-concern qualified opinion (IGCQ) for audited clients is a complicated and difficult process after auditors carefully review management plans for solving going-concern uncertainties and evaluate their feasibility based on the Generally Accepted Auditing Standards (GAAS) (Bruynseels et al., 2011; Citron and Taffler, 1992).

A disclosed IGCQ causing client bankruptcy is called "the self-fulfilling prophecy effect". Clients in financial hardship often switch auditors after an IGCQ (Menon and Schwartz, 1985; Tucker et al., 2003; Vanstraelen, 2003). Thus, this study intends to answer two questions. First, does the self-fulfilling prophecy effect exist? The evidence has been inconsistent (Citron and Taffler, 1992, 2001; George et al., 1996; Guiral, 2011; Louwers et al., 1999; Mutchler, 1984; Tucker and Matsumura, 1998;). Disclosed IGCQs accompany complex and unobservable factors. The inconsistent evidence may also vary due to different definitions of financial hardship or bankruptcy in the capital market. Bankruptcy is a legal process claiming a debtor's insolvency and specifying a series of steps to liquidation. Countries' different laws define and recognize bankruptcy differently.

Prior studies have discussed the different impacts of debtor- or creditor-oriented corporate bankruptcy systems (Charitou et al., 2007; Franken, 2004; Franks et al., 1996). Under United States Code Title 11 Bankruptcy law, in Chapter Seven for liquidation and Chapter Eleven for reorganization, the insolvency codes are primarily debtor-oriented. Legal bankruptcy procedures might force the bankrupt company to discontinue operations. However, creditor-oriented codes in British, Germany, Australia, and New Zealand make liquidation a normally adopted tactic for insolvent companies. Unfortunately, for companies in creditor-oriented countries, liquidation costs always exceed bankruptcy costs, which put their shareholders and other interested parties in relatively disadvantaged positions (Carver, 2012). Hence, a bankruptcy prediction model to evaluate the effect of IGCQ may be inappropriate when companies are regulated by the creditor-oriented codes (Kuruppu et al., 2003).

In the U.S., when public companies experience financial hardships like bankruptcy, the Security Exchange Commission (SEC) may order the company shares to stop margin trading or even delist. Stocks may therefore experience lower liquidity and trading volume, and their prices may plummet. Investors will have lost essentially all their investments, making future bankruptcy evaluation meaningless. Because of the definitions of corporate bankruptcy is 
varied in countries, it would be biased to interpret research results when evaluating the impacts of possible bankruptcy on stock investors. Besides, it is still unclear if public firms, subject to trading restrictions such as stop margin trading, trading suspension, or delisting, should be treated as bankruptable in current Taiwanese corporate law. As a result, this study uses delisting of Taiwanese public firms as the sample to represent firms in financial hardship, not firms in bankruptcy.

The second research question concerns auditor switching to promote understanding about competition and expertise involved in the audit market. The SEC requires public companies to disclose auditor switching in the hope that auditors can perform their service independently without considering client preferences. Reasons for auditor switching should also be reported, such as changes in management, additional audit service needed, dissatisfaction or disagreement with the overall audit report, or conflicts in audit fees (Addams and Davis, 1994; Cassell et al., 2012; Chang et al., 2010; Defond, 1992; Feng, 2013; Menon and Schwartz, 1985; Menon and Williams, 1991;Schwartz and Soo, 1996; Thevenot and Hall, 2011). Menon and Schwartz (1985) study the possibility of auditor switching for firms in trouble and the influence of the capital market on the demand for audit service. Their research concludes that financial hardship has a high correlation with auditor switching. Unfortunately, their research focuses on a certain particular sample, which could cause selection bias. In addition, the research applies the univariate test on only one explanatory variable of firms in financial trouble for auditor switching, ignoring other possible variables.

Client decisions in the audit market may cause reactions in the stock market. A disclosed IGCQ may precipitate corporate delisting or bankruptcy. Delisting may lead to auditor switching as well. Previous research merely discusses the effects of audit decisions on audit or stock market, but neglects the possibility of an interaction between different market behaviors within the same economic environment, or excludes other unobservable interference factors. Therefore, this study aims to examine the possible adverse effects of an IGCQ, with five main topics:

(1) Whether other unobserved factors influence the audit and stock markets at once.

(2) Whether companies in financial hardship are more likely to switch auditors (re-examined considering sample selection bias).

(3) Whether delisting influences auditor switching. That is, if there exists an endogenous problem between auditor switching and delisting.

(4) Whether disclosed IGCQs cause delisting: that is, whether the self-fulfilling prophecy effect exists in Taiwanese stock market.

(5) Whether auditor switching follows disclosure of IGCQs immediately.

This study includes a literature review on the self-fulfilling prophecy effect and auditor switching, research design to explain variables measured, specification of the bivariate probit model and empirical model, research results and analysis, sensitivity analysis for the empirical model, and a conclusion. 


\section{Literature Review}

After the issuance of an IGCQ, the client may go bankrupt or switch auditors. Either of these circumstances would harm the CPA firm, directly or indirectly. Client bankruptcy may damage its reputation and thus drive away future clients or current ones, leading to losses of audit and non-audit revenues. The following is a review of studies of the self-fulfilling prophecy effect and auditor switching.

\subsection{The Self-Fulfilling Prophecy Effect}

The main role that an auditor plays is to disclose information of the client, not to evaluate the risks associated with the client (Islam, 2013). However, an IGCQ can expedite a client's failure, exerting a bad influence on current and potential investors, creditors, suppliers, and consumers (Carcello and Vanstraelen, 2009). When this early warning leads to client bankruptcy, it is called the self-fulfilling prophecy effect (Mutchler, 1984). From direct interviews, Mutchler (1984) found that auditors generally consider potential impacts on clients in an IGCQ. However, most did not believe in the self-fulfilling prophecy effect. Tucker and Matsumura (1998) based on game theory, correlated the predicted variable and reactive factor. Their models show that when the opinion pattern is self-fulfilling in the predicted variable, auditors are less likely to issue an IGCQ although their results do not conform to economists' prediction. That may due to their overall risk aversion.

Moreover, there is no consensus in research about the self-fulfilling prophecy effect. Citron and Taffler (1992) sampled 86 British companies that received IGCQs and controlled for company size, year, industry category, and financial conditions, intending to distinguish IGCQs' impacts. They found that one year after the IGCQ was issued, 21 out of the 86 sample companies were bankrupt. Surprisingly, of a matched control group of 86 companies that did not receive IGCQs, 22 declared bankruptcy. They found no evidence of the self-fulfilling prophecy effect. Louwers et al. (1999) found no proof of it either. However, Nogler (1995), using a sample of 157 American companies that received IGCQs from 1983-1990, found that 33\% of them were bankrupt later and 30\% experienced an organizational restructure such as mergers, liquidation, or dissolution, supporting the idea of the self-fulfilling prophecy effect. In addition, George et al. (1996) also indicated the existence of self-fulfilling prophecy effect. Therefore, before any further discussion about this topic, it is necessary to investigate variations in others' research methods and their data collecting processes. However, Citron and Taffler (2001) proposed the degree of financial distress that drives both client bankruptcy and the auditor's going concern disclosure rather than the disclosure itself that causes client failure.

Based on motivated reasoning and belief-adjustment model, Guiral et al. (2011) proved the self-fulfilling prophecy that auditors' expectations affected their attitudes toward the evidence in the going concern setting from a laboratory experiment. On the other hand, Louwers et al. (1999) provided three critical problems with verifying the self-fulfilling prophecy effect. First, it is hard to clarify whether the qualified audit opinion can be an indicator for financial hardships. Second, if it is, it is uncertain whether it causes bankruptcy or reflects other factors that cause bankruptcy. Third, due to limits on information, auditors may not able to 
thoroughly evaluate foreseeable impacts on the client's future operations after the IGCQ is issued. It is impossible for auditors to issue different opinions when going-concern uncertainties exist, and yet if they do, the client may still go bankrupt.

This study applies the following methods to overcome these limitations and those cited by Citron and Taffler (1992). For the sample design, we further divide companies into two sub-sample groups, delisting and non-delisting. The IGCQ variable is included in the model to verify its predictive power of delisting when controlling other factors. In addition, this study also examines if the audit opinion, independently or concurrently with other unobserved variables, affects client delisting.

\subsection{Auditor Switching}

Previous studies have tested audit fees, auditor's active reactions toward clients, corporate mergers and acquisitions, manager changes, effects of corporate governance, lack of beneficial reactions, stock market reaction, management's disagreement with audit reports, and corporate financial hardships as possible reasons for auditor switching (Addams and Davis, 1994; Asthana et al., 2010; Cassell et al., 2012; Chang et al., 2010; Chen et al., 2010; Lopez et al., 2011; Menon and Schwartz, 1985; Schwartz and Soo, 1996; Stunda, 2012; Yanan et al., 2013). Other issues relating to auditor switching are initial public offering (Menon and Williams, 1991), agent conflict and relative size (Defond, 1992), adverse internal control audit opinion (Thevenot and Hall, 2011), the effect of December fiscal year-end (Feng, 2013).

Certain studies have shown that when clients received IGCQs, auditor switching obviously is more likely to occur (Citron and Taffler, 1992; Krishnan and Stephens, 1995; Lennox, 2000; Tucker et al., 2003; Vanstraelen, 2003). Menon and Schwartz (1985), however, did not discover that relation. Auditors become more conservative in their going-concern judgments and the resulting audit opinion decision (Anderson, 2011; Stunda and Pacini, 2013). In addition, empirically supports that when an audit report is changeable, auditor switching is easy (Lennox, 2000). A Belgian study discovers that the threat of switching can effectively remove an auditor's autonomy (Vanstraelen, 2003).

Most auditor switching studies have adopted statistical independence tests and applied univariate tests on two variables. However, a contradiction about research methods is found in the studies of Menon and Schwartz (1985). Three factors may have led to their dissenting results: particular and different sample sets, unobserved variables, and occasional intervening variables. This study focuses on the association of auditor switching and delisting from the Taiwanese stock market. We also investigate unobserved variables to clarify the existence of additional causal relationships.

\section{Research Design}

Table 1A describes research variables and Table 1B describes the testing models as shown. According to Citiron and Taffler's corporate bankruptcy model (1992, 2001), we uses a dummy dependent variable to represent whether the firm incurs delisting (DELIST, binary). A dummy variable for auditor switching (SWITCH, binary) is the same as in Menon and 
Schwartz (1985) and Vanstraelen (2003).

Our empirical model includes five control variables. The age variable (AGE, years) comes from Chen and Lee (1993) who use the age of the market listing period to predict the probability of bankruptcy. A longer listing period enables firms to accumulate greater profitability and smoother operation. Thus, we predict the longer AGE is, the lower the possibility of delisting. The second control variable represents a client's reported loss (LOSS, binary). When a company reports a loss, it signals its financial condition is weak and more likely to fail. The third control variable represents audit report quality. Users generally incorporate such quality into their investment or credit decisions. We include a dummy variable by a "Big Four" CPA firm audit (B4, binary) to proxy audit quality as in the Krishnan (1994) model. The fourth control variable is the firm size (SIZE, nature log of total assets). Citiron and Taffler (1992, 2001) and Haskins and Williams (1990) agree that larger companies are less likely to fail because they have longer history and more resources to support their operation. Banks and interested parties prefer to support larger firms that have more to lose in costs and unfavorable news if they fail. Therefore, we expect that the larger the company, the less likely delisting is. The fifth control variable represents the degree of financial hardship (FINANCE) by adopting a z-score composite financial hardship index according to the model of Altman (1968) and Cititron and Taffler (2001). If the z-score is lower, the company is in more serious financial hardship and more likely to fail. The z-linear index is based on a series of financial ratios of the following: $\mathrm{Z}_{\mathrm{i}}=0.012 \mathrm{X}_{1}+0.014 \mathrm{X}_{2}+$ $0.033 \mathrm{X}_{3}+0.0064 \mathrm{X}_{4}+0.999 \mathrm{X}_{5}$, where $\mathrm{X}_{1}=$ [(current asset - current liabilities)/total assets], $\mathrm{X}_{2}=$ [retained earnings/total assets], $\mathrm{X}_{3}=$ [income before interests and taxes/total assets], $\mathrm{X}_{4}=$ [the market value of total equity/total liabilities], and $\mathrm{X}_{5}=$ [sales revenues/total assets]. 
Table 1A. Research variable definition

\begin{tabular}{|c|c|c|}
\hline \multicolumn{2}{|l|}{ Variable } & Definition \\
\hline \multicolumn{2}{|l|}{ DELIST } & Whether the client is delisted from the stock market \\
\hline \multicolumn{2}{|l|}{ AGE } & The years of market delisting \\
\hline \multicolumn{2}{|l|}{ IGCQ } & $\begin{array}{l}\text { Whether the client is issued with an initial going-concern } \\
\text { qualified audit opinion }\end{array}$ \\
\hline \multicolumn{2}{|l|}{ RGCQ } & $\begin{array}{l}\text { Whether the client is issued with a repeated going-concern } \\
\text { qualified audit opinion }\end{array}$ \\
\hline \multicolumn{2}{|l|}{ IGCQY1 } & The client incurs auditor switching one year after IGCQ \\
\hline \multicolumn{2}{|l|}{ IGCQY2 } & The client incurs auditor switching two years after IGCQ \\
\hline \multicolumn{2}{|l|}{ IGCQY3 } & The client incurs auditor switching three years after IGCQ \\
\hline \multicolumn{2}{|l|}{ LOSS } & The client reporting loss during the sample period \\
\hline \multicolumn{2}{|l|}{ B4 } & The client audited by a big four CPA firm \\
\hline \multicolumn{2}{|l|}{ SIZE } & The market value of the client \\
\hline \multicolumn{2}{|l|}{ SWITCH } & Whether the client incur audit switching \\
\hline \multicolumn{2}{|l|}{ FINANCE } & $\begin{array}{l}\text { A Z-score composite index, the degree of financial hardships } \\
\text { of the client (the lower Z-score, the worse its financials) }\end{array}$ \\
\hline \multicolumn{3}{|c|}{ Table 1B: The testing models } \\
\hline Model & Equations & $\underline{\text { Statistical method }}$ \\
\hline A & (10), (11) & Bivariate probit model \\
\hline B & (12), (13) & Recursive simultaneous equation \\
\hline $\mathrm{C}$ & $(14),(15)$ & Recursive simultaneous equation \\
\hline $\mathrm{D}$ & (16) & Delisting (DELIST) model for comparison with model A \\
\hline E & $(17)$ & Switching (SWITCH) model for comparison with model A \\
\hline
\end{tabular}

To understand causes for auditor switching, we also employ the five control variables in the switching model according to prior studies (Krishnan, 1994; Menon and Schwartz, 1985). However, client size inhibits auditor switching (Haskins and Williams, 1990; Krishnan, 1994) since smaller firms grow rapidly in general and tend to switch to bigger CPA firms unlike larger firms, who are deterred by higher switching costs. Sample selection bias occurs when the sample is not selected randomly but only from clients issued with IGCQ. To overcome the bias, we apply the bivariate probit method, which can reveal unobservable factors affecting delisting and auditor switching. The research model is designed as follows:

$$
\begin{aligned}
& Y_{1}^{*}=X_{1}^{\prime} \beta_{1}+\varepsilon_{1} \\
& Y_{2}^{*}=X_{2}^{\prime} \beta_{2}+\varepsilon_{2}
\end{aligned}
$$


where $Y_{1}{ }^{*}$ is the latent propensity for client delisting and a vector $\mathrm{X}_{1}{ }^{\prime}$ is the observed variables affecting $Y_{1}{ }^{*}$. In addition, let $Y_{2}{ }^{*}$ be the latent propensity for the client to switch auditors and vector $X_{2}$ ' be the observed variables influencing $Y_{2}{ }^{*} . Y_{i}{ }^{*}$ is unobservable and relates to the binary explanatory variable, based on the following:

$$
\begin{aligned}
& Y_{1}=1 \text {, if } Y_{1}^{*} \succ 0 ; Y_{1}=0 \text {, if } Y_{1}^{*} \leq 0 \text { and } \\
& Y_{2}=1 \text {, if } Y_{2}^{*} \succ 0 ; Y_{2}=0 \text {, if } Y_{2}^{*} \leq 0
\end{aligned}
$$

where $Y_{1}=1$ when the client is delisted and $Y_{2}=1$ when the auditors are switched. The error term $\left(\varepsilon_{1}, \varepsilon_{2}\right)$ is supposed to be a standard bivariate normal distribution, $f\left(\varepsilon_{1}, \varepsilon_{2}\right) \sim \mathrm{N}\left(\begin{array}{ll}1 & \rho \\ \rho & 1\end{array}\right), \quad E\left(\varepsilon_{1}\right)=E\left(\varepsilon_{2}\right)=0, \quad V\left(\varepsilon_{1}\right)=V\left(\varepsilon_{2}\right)=1, \quad \operatorname{cov}\left(\varepsilon_{1}, \varepsilon_{2}\right)=\rho$. Equations (1) and (2) have the same related error terms with random disturbances for both latent propensities of delisting and auditor switching.

Therefore, both possibilities of delisting and auditor switching could be written into the following:

$$
\begin{aligned}
& P\left(Y_{1}=1, Y_{2}=1\right)=P\left(X_{1} \prec x_{1}, X_{2} \prec x_{2}\right) \\
& =\int_{-\infty}^{x_{2}} \int_{-\infty}^{x_{1}} \phi_{2}\left(z_{1}, z_{2} ; \rho\right) d z_{1} d z_{2}=F\left(X_{1} \beta_{1}, X_{2} \beta_{2} ; \rho\right)
\end{aligned}
$$

where $\mathrm{F}$ has a correlation coefficient of $\rho$ which has a bivariate standard normal distribution function. The maximum likelihood method estimates the parameters in the model, with a function as the following:

$$
\begin{gathered}
\ln L\left(\beta_{1}, \beta_{2}, \rho\right)=\sum_{i=1}^{n}\left\{Y_{1} \times Y_{2} \ln F\left(X_{i 1} \beta_{1}, X_{i 2} \beta_{2} ; \rho\right)+Y_{1}\left(1-Y_{2}\right)+\right. \\
\left.\ln \left[\phi\left(X_{i 1} \beta_{1}, X_{i 2} \beta_{2} ; \rho\right)\right]+\left(1-Y_{1}\right) \ln \phi\left(-X_{i 1} \beta_{1}\right)\right\}
\end{gathered}
$$

where $\phi$ is a standard normal distribution function.

We also investigate if delisting and auditor switching interact concurrently within the same economic environment. The recursive bivariate probit model, called the recursive simultaneous equations model, verifies the relation as in the following (Greene, 2003; Maddala, 1983):

$$
\begin{aligned}
& Y_{1}^{*}=X_{1}^{\prime} \beta_{1}+\varepsilon_{1}, Y_{1}=1\left(Y_{1}^{*} \succ 0\right) \\
& Y_{2}^{*}=X_{2}^{\prime} \beta_{2}+\gamma_{2} Y_{1}+\varepsilon_{2}, Y_{2}=1\left(Y_{2}^{*} \succ 0\right)
\end{aligned}
$$


where $Y_{1}=1$, when the client is delisted, is also the dependent variable in equation (7) and $Y_{2}=1$, when the client switches auditors, is the independent variable in equation (8) which also includes the endogenous variable of $Y_{1}$. The dependent variables are those included in the vectors of $\mathrm{X}_{1}{ }^{\prime}$ and $\mathrm{X}_{2}{ }^{\prime}$ in equation (7) and (8). The error term $\varepsilon_{1}, \varepsilon_{2}$ in equations (7) and

(8) is a standard bivariate normal distribution with a correlation coefficient of $\rho$.

$$
f\left(\varepsilon_{1}, \varepsilon_{2}\right) \sim \mathrm{N}\left(\begin{array}{cc}
1 & \rho \\
\rho & 1
\end{array}\right), E\left(\varepsilon_{1}\right)=E\left(\varepsilon_{2}\right)=0, V\left(\varepsilon_{1}\right)=V\left(\varepsilon_{2}\right)=1, \operatorname{cov}\left(\varepsilon_{1}, \varepsilon_{2}\right)=\rho
$$

To discuss how a repeated opinion influences delisting and auditor switching, we further distinguish between ordinary IGCQs and repeated going-concern qualified opinions (hereafter RGCQ) in equation (10). Because of the time lapse between IGCQ and client bankruptcy, other factors or even an RGCQ affecting bankruptcy may complicate the self-fulfilling prophecy effect. If the RGCQ is proven insignificant, the qualified opinion itself may not be a substantial factor in delisting.

In addition, according to Menon and Schwartz (1985) and Vanstraelen (2003), we wait three years after the IGCQ to discover auditor switching in Taiwan. Empirically this study assumes auditor switching may be occur one year after IGCQ (hereafter IGCQY1), two years after (IGCQY2), and three years after (IGCQY3). In our study, the sample is divided into audit clients with and without IGCQ so we can compare the two sub-sample groups. Therefore, whether we should attribute auditor switching to the IGCQ or simply to the client's original financial hardships could be clear, since previous studies suggest firms in financial hardship are more likely to switch auditors. The empirical model is below (11):

$$
\begin{aligned}
& \text { DELIST }=f(\text { IGCQ, RGCQ }, \text { AGE }, \text { LOSS }, \text { B4, SIZE }, \text { FINANCE }) \\
& \text { SWITCH }=f(I G C Q Y 1, \text { AGE }, B 4, \text { SIZE }, \text { FINANCE })
\end{aligned}
$$

We also need to verify whether delisting and auditor switching are mutually causally related. Since the two events are binary variables, the recursive bivariate probit model is appropriate to test them. Thus, in equation (12), auditor switching is an endogenous variable in the bankruptcy model to explain delisting. In addition, equations (12) and (13) also use the bivariate probit model to test if the two events are subject to other vital unobservable factors called unspecified variables. Similarly, in equation (15) for auditor switching model, another endogenous variable for delisting is used to test its effect on auditor switching as stated in the following recursive bivariate probit model to estimate equation (14) and (15).

$$
\begin{aligned}
& \text { DELIST }=f(\text { SWITCH }, \text { IGCQ }, \text { RGCQ }, A G E, \text { LOSS }, \text { B4, SIZE }, \text { FINANCE }) \\
& \text { SWITCH }=f(I G C Q Y 1, A G E, B 4, \text { SIZE, FINANCE })
\end{aligned}
$$




$$
\begin{aligned}
\text { DELIST } & =f(I G C Q, R G C Q, A G E, \text { LOSS }, \text { B4, SIZE, FINANCE }) \\
\text { SWITCH } & =f(\text { DELIST }, \text { IGCQY1, AGE }, \text { B4, SIZE, FINANCE })
\end{aligned}
$$

For comparison with the bivariate prodbit model in equations (10-15), equation (16) and (17) are added to determine delisting and audit switching respectively.

$$
\begin{aligned}
& \text { DELIST }=f(\text { IGCQ, RGCQ }, \text { AGE }, \text { LOSS , B4, SIZE , FINANCE }) \\
& \text { SWITCH }=f(\text { IGCQY1, IGCQY 2, IGCQY 3, AGE , B4, SIZE, FINANCE })
\end{aligned}
$$

\section{Sample Design and Empirical Results}

The sample design divides Taiwanese public firms into three sub-sample groups based on previous studies (Citron and Taffler, 1992, 2001; Louwers et al., 1999). The first group includes 34 public firms receiving IGCQs from 1987 to 2010 but continued operation until the end of research. The second group includes 167 already delisted companies who received IGCQs during the same period. The third group is the control group with a total of 557 public companies being in operation who may receive IGCOs during the sample period. Only public firms with complete information are included into the entire sample. Criteria used to match samples are sample period, industry classification, and company size. All sample data was obtained from the Market Observation Post System of the Taiwan Stock Exchange and from the Taiwan Economic Journal.

Table 2A\&2B provide sub-sample firm distribution by audit opinion (IGCQ: 26.5\% vs. non-IGCQ: $73.5 \%$ ), delisting (yes: $71.0 \%$ vs. no: $29.0 \%$ ) and auditor switching (yes: $20.1 \%$ vs. no: $79.9 \%)$ to examine the self-fulfilling prophecy effect in Taiwan. To verify model stability, firms were further divided into sub-sample groups of delisting and auditor switching. 


\section{Macrothink}

Table 2A.: Sub-sample firm numbers by audit opinion and market delisting

\begin{tabular}{|c|c|c|c|}
\hline \multirow[t]{2}{*}{$\underline{\text { If IGCQ firms }}$} & \multicolumn{3}{|c|}{$\underline{\text { If market delisting firms }}$} \\
\hline & $\underline{\mathrm{No}}^{\dagger}$ & $\underline{\text { Yes }}$ & $\underline{\text { Total }}$ \\
\hline Yes ${ }^{\pi}$ & 34 & 167 & $201(26.5 \%)$ \\
\hline No & 504 & 53 & $557(73.5 \%)$ \\
\hline Total & $538(71.0 \%)$ & $220(29.0 \%)$ & $758(100.0 \%)$ \\
\hline \multicolumn{4}{|c|}{ Table 2B: Sub-sample firm numbers by audit opinion and auditor switching } \\
\hline \multirow[t]{2}{*}{$\underline{\text { If IGCQ firms }}$} & \multicolumn{3}{|c|}{$\underline{\text { If auditor switching firms }}$} \\
\hline & $\underline{\text { No }}$ & $\underline{\text { Yes }}$ & $\underline{\text { Total }}$ \\
\hline Yes & 49 & 152 & $201(26.5 \%)$ \\
\hline No & 557 & 0 & 557 (73.5\%) \\
\hline Total & 606 (79.9\%) & $152(20.1 \%)$ & $758(100.0 \%)$ \\
\hline
\end{tabular}

not occurring market delisting or auditor switching until sampling time in 2010.

occurring market delisting or auditor switching during the period of 1987-2010.

^ if firms issued with IGCQ during 1987-2010.

$\S$ total sample includes 758 public firms and a sub-sample of 557 (73.5\%) non-IGCQ firms is the controlling sample, matching with 201 IGCQ firms (26.5\%) based on the year, industry, and companies size.

Table 3 states the descriptive statistics for the research variables. Delisted firms consist of $29 \%$ of the entire sample, with a ratio of 1:2.5 to non-delisted firms. The ratio is not $1: 1$ to avoid overestimating the sample of delisted firms. Auditor-switching firms consist of $20 \%$ of the sample. Among IGCQ firms, there are 167 delisting firms, 34 non-delisting firms and 152 auditor switching firms. Of the entire sample firms, $26.5 \%$ are IGCQ firms and 15.4\% are RGCQ firms. There are 11.1\% IGCQ firms incurring auditor switching one year after the IGCQ. Among the IGCQ firms, $44.9 \%$ of delisting firms also have auditor switching but only $26.4 \%$ of non-delisting firms have switching. About 10\% of IGCQ firms have auditor switching in the next year after the IGCQ of which delisting firms are twice likely to switch auditors than those non-delisting ones. 
Table 3. Descriptive statistics of research variables

\begin{tabular}{llllll} 
Variable & Mean & Median & Std. Dev. & Max & Min \\
\hline AGE (years) & $14.972^{\dagger}$ & 12 & 9.504 & 48 & 1 \\
& & & & & \\
& $(18.411)^{\star}$ & $(16)$ & $(9.198)$ & $(47)$ & $(6)$ \\
& & & & & \\
& {$[18.916]^{\natural}$} & {$[17]$} & {$[10.183]$} & {$[48]$} & {$[4]$} \\
SIZE & & & & & \\
(nature log, & $(15.465)$ & $(15.94)$ & $(1.702)$ & $(18.732)$ & $(12.65)$ \\
total assets) & {$[14.871]$} & {$[14.947]$} & {$[1.373]$} & {$[18.057]$} & {$[7.282]$} \\
& & & & & \\
FINANCE & 1.626 & 0.975 & 4.453 & 73.71 & -0.10 \\
& $(0.758)$ & $(0.65)$ & $(0.607)$ & $(3.095)$ & $(0)$ \\
& {$[1.094]$} & {$[0.848]$} & {$[1.217]$} & {$[12.676]$} & {$[0]$} \\
\hline
\end{tabular}

Numbers without any bracket are for the total 557 sample

Numbers in parentheses ( ) are for the sub-sample 34 IGCQ but non-delisting firms

I Numbers in square brackets [ ] are for the sub-sample 167 IGCQ but delisting firms

Table 4 is a correlation matrix for the delisting firms, auditor switching firms, the predicted and control variables. There is positive correlation (0.751) between delisting and switching auditors. Positive correlations are also found for the delisting firms with the IGCQ firms (0.855) but with RGCQ firms (0.601), as well as for the auditor switching firms with the IGCQ firms (0.834) but with the RGCQ (0.634). Thus, many IGCQ firms may experience delisting and/or auditor switching soon after their IGCQ but not before the RGCQ. The correlation between IGCQ and auditors switching at one year later is 0.684 , revealing the auditor switching generally occurs within one year of the IGCQ. However, there is insignificant correlation between the degree of financial hardships (low FINANCE index) and delisting. That may be due to the time required for serious financial hardships to develop and actually lead to delisting. The significant negative correlation $(-0.79)$ between IGCQ and FINANCE confirms that firms in financial hardships (lower FINANCE) are generally those clients with IGCQ.

As to the appropriateness of the bivariate probit model, first, the chi-square $X^{2}$ test is applied to three sets of simultaneous equations of the bivariate probit model and the recursive models of $\mathrm{B}$ and $\mathrm{C}$. All the models employed are significant at less than $1 \%$ level, indicating the probit and recursive simultaneous equations models are appropriate methods. Based on the correlation coefficient matrix in Table 4 , a positive significant correlation $(0.751$ at $<1 \%)$ is 
found between delisting and auditor switching, supporting the joint model estimation.

Table 4. The correlation coefficient matrix

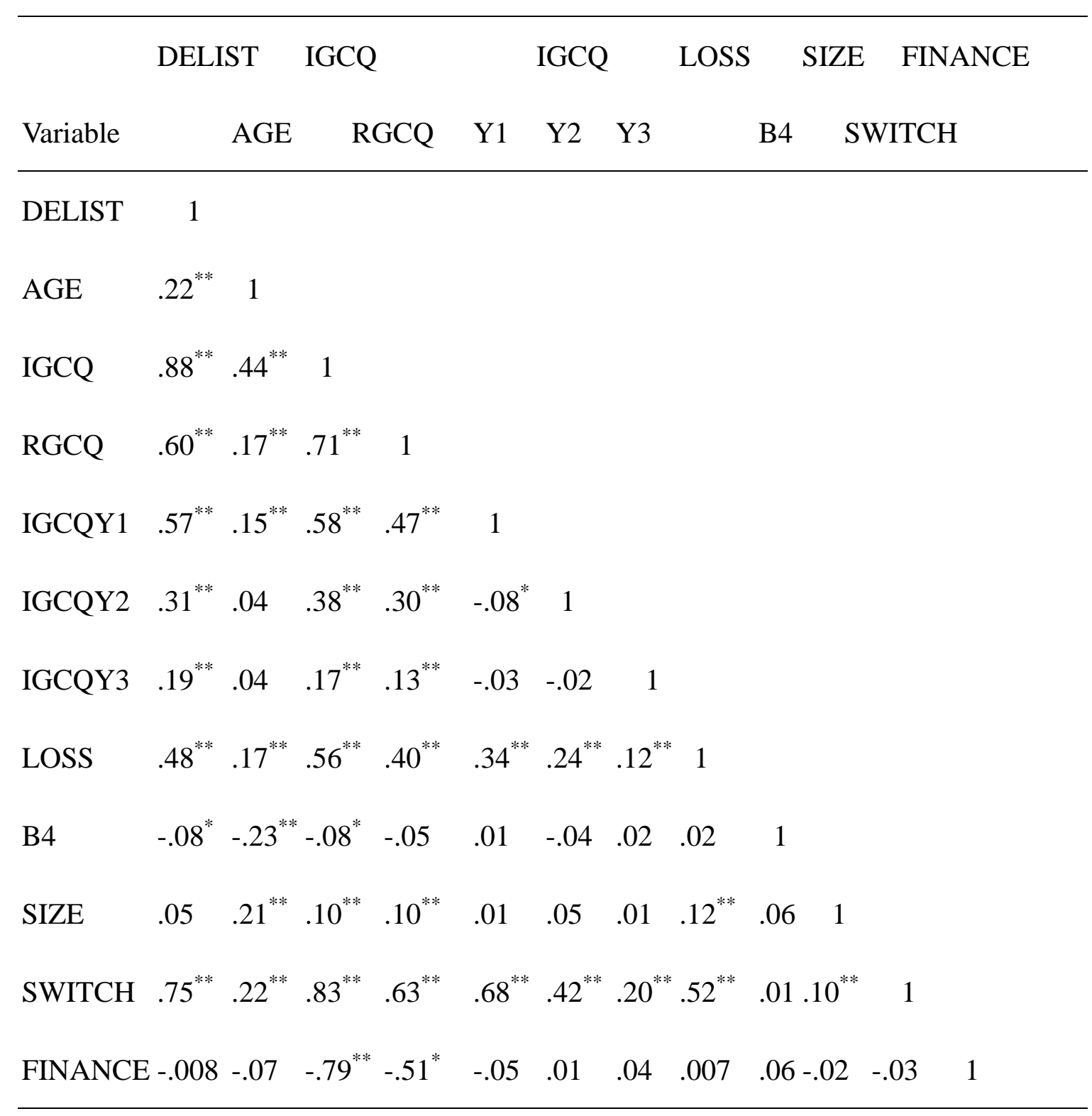

*** Significant at $1 \%$ level, ** at $5 \%$, and * at $10 \%$.

In Table 5, the bivariate probit model shows the estimated correlation coefficients, $\rho$, of 0.752, 0.797 , and 0.763 are all significantly different from zero at $1 \%$ level for model A, B, and $\mathrm{C}$ respectively. That reveals both delisting and auditor switching are subject to the impacts of unobservable factors within the model such as cycles in economic and changes in financial system. Based on these significant correlations, both models of delisting and auditor switching should be estimated jointly in empirical testing by two equations according to their 
correlations.

Based on the empirical results from the three sets of $\mathrm{A}, \mathrm{B}$, and $\mathrm{C}$ bivariate simultaneous equations, the IGCQ does not affect delisting significantly, neither does the RGCQ influence the delisting significantly, even when the financial hardships variable is controlled for in the model. However, our results agree with those of Citron and Taffler (2001). In conclusion, we cannot support the self-fulfilling prophecy effect in the Taiwanese stock market because the time lapse between IGCQ and delisting interferes with the result. In addition, by excluding IGCQs and financial hardships, unobservable factors in other markets in the same economic environment may contribute to delisting, confirmable by significant estimated correlation coefficients $\rho$ in the bivariate probit models. From the B model, the auditor switching variable (SWITCH) has a significant impact on delisting (DELIST). The C model shows that clients in financial hardships tend to switch auditors, which verifies Menon and Schwartz (1985)'s assertion that delisting leads to auditor switching. Other changes in the stock market would also influence the demand for audit services.

Based on the estimation results of the A, B, and E model, factors influencing auditor switching are all significant. One year after the IGCQ (IGCQY1), companies are most likely to switch auditors. Model $\mathrm{C}$ also reveals that delisting raises the probability of auditor switching significantly. Model E studies individual behaviors in the audit market and finds auditor switching likely in IGCQY1 and IGCQY2 but not IGCQY3. Although the audit market is highly regulated, auditors are subject to replacement with short notice by unsatisfied clients. Model D only considers factors causing client delisting when its financial conditions are controlled. Empirical results confirm our hypothesis that the correlation between audit and stock market may interfere with the explanation of delisting. Indeed, IGCQ and financial hardships do not cause delisting but other market correlations in the same economic environment may be. Model D also supports previous findings (Citron and Taffler, 1992) that corporate bankruptcy is not related to financial hardship. However, differences in variable measurements and definitions should be handled with more attention. In this study, the degree of financial hardship is measured at one year before the IGCQ issued, because delisting generally occurs after an IGCQ. Earlier financial hardships are attributable to IGCQ but not necessarily to delisting as stated in Citron and Taffler (1992) findings. Therefore, we conclude that early financial hardships should not be the main cause for client delisting. Notice that we proxy bankruptcy by delisting which is different from previous measurements for corporate failure. Delisting in general causes company shares to lose liquidity but it does not necessarily lead to bankruptcy immediately. Consequently, any interpretation should be made with caution for there are different meanings among variables employed. 
Table 5. Results of bivariate probit model

\begin{tabular}{|c|c|c|c|c|c|c|c|c|}
\hline Model & & $\mathrm{A}$ & & B & & $\mathrm{C}$ & $\mathrm{D}$ & $E$ \\
\hline Variable & $\begin{array}{l}\text { DELIST } \\
\text { (SD) }\end{array}$ & SWITCH & DELIST & SWITCH & DELIST & SWITCH & DELIST & SWITCH \\
\hline CONSTAN & $\begin{array}{l}-238 \\
(28710)\end{array}$ & $\begin{array}{l}-2.84^{* * *} \\
(.28)\end{array}$ & $\begin{array}{l}-4.08 \\
(92.07)\end{array}$ & $\begin{array}{l}-2.81^{* *} \\
(.28)\end{array}$ & $\begin{array}{l}-3.99 \\
(93.26)\end{array}$ & $\begin{array}{l}-3.45^{* *} \\
(.36)\end{array}$ & $\begin{array}{l}-151.6 \\
\left(2.2 \times 10^{5}\right)\end{array}$ & $\begin{array}{l}-3.38^{* *} \\
(.35)\end{array}$ \\
\hline DELIST & & & & & & $\begin{array}{l}2.27^{* *} \\
(.17)\end{array}$ & & \\
\hline SWITCH & & & $\begin{array}{l}1.44^{* * *} \\
(.19)\end{array}$ & & & & & \\
\hline IGCQ & $\begin{array}{l}241 \\
(28710)\end{array}$ & & $\begin{array}{l}5.73 \\
(92.54)\end{array}$ & & $\begin{array}{l}5.51 \\
(93.44)\end{array}$ & & $\begin{array}{l}154.8 \\
\left(1.5 \times 10^{5}\right)\end{array}$ & \\
\hline RGCQ & $\begin{array}{l}-.22 \\
(.22)\end{array}$ & & $\begin{array}{l}-.25 \\
(.16)\end{array}$ & & $\begin{array}{l}-.20 \\
(.22)\end{array}$ & & $\begin{array}{l}-.22 \\
(.22)\end{array}$ & \\
\hline IGCQY1 & & $\begin{array}{l}3.12 * * * \\
(.35)\end{array}$ & & $\begin{array}{l}3.06 * * \\
(.34)\end{array}$ & & $\begin{array}{l}1.66^{* *} \\
(.38)\end{array}$ & & $\begin{array}{l}3.62 * * \\
(.37)\end{array}$ \\
\hline IGCQY2 & & & & & & & & $\begin{array}{l}3.14^{* *} \\
(.4)\end{array}$ \\
\hline IGCQY3 & & & & & & & & $\begin{array}{l}8.57 \\
\left(1.4 \times 10^{5}\right)\end{array}$ \\
\hline AGE & $\begin{array}{l}.005 \\
(.01)\end{array}$ & $\begin{array}{l}.027^{* *} \\
(.09)\end{array}$ & $\begin{array}{l}.01 \\
(.01)\end{array}$ & $\begin{array}{l}.02^{* *} \\
(.009)\end{array}$ & $\begin{array}{l}.001 * \\
(.01)\end{array}$ & $\begin{array}{l}.022 * \\
(.01)\end{array}$ & $\begin{array}{l}.004 \\
(.001)\end{array}$ & $\begin{array}{l}.03^{* *} \\
(.01)\end{array}$ \\
\hline LOSS & $\begin{array}{l}-.25 \\
(.44)\end{array}$ & & $\begin{array}{l}-1.15^{* * *} \\
(.33)\end{array}$ & & $\begin{array}{l}-.33 \\
(.47)\end{array}$ & & $\begin{array}{l}-.28 \\
(.30)\end{array}$ & \\
\hline B4 & $\begin{array}{l}.07 \\
(.24)\end{array}$ & $\begin{array}{l}.11 \\
(.17)\end{array}$ & $\begin{array}{l}-.05 \\
(.20)\end{array}$ & $\begin{array}{l}.15 \\
(.16)\end{array}$ & $\begin{array}{l}.001 \\
(.25)\end{array}$ & $\begin{array}{l}.28 \\
(.19)\end{array}$ & $\begin{array}{l}.08 \\
(.23)\end{array}$ & $\begin{array}{l}.32 \\
(.21)\end{array}$ \\
\hline SIZE & $\begin{array}{l}-.15^{*} \\
(.08)\end{array}$ & $\begin{array}{l}.001 \\
(.004)\end{array}$ & $\begin{array}{l}-.002 \\
(.05)\end{array}$ & $\begin{array}{l}.001 \\
(.004)\end{array}$ & $\begin{array}{l}-.001 \\
(.03)\end{array}$ & $\begin{array}{l}.001 \\
(.02)\end{array}$ & $\begin{array}{l}-.14^{*} \\
(.07)\end{array}$ & $\begin{array}{l}.001 \\
(.002)\end{array}$ \\
\hline FINANCE & $\begin{array}{l}.05 \\
(.10)\end{array}$ & $\begin{array}{l}.08 \\
(.05)\end{array}$ & $\begin{array}{l}.20 \\
(.18)\end{array}$ & $\begin{array}{l}.08 \\
(.05)\end{array}$ & $\begin{array}{l}.42 \\
(.16)\end{array}$ & $\begin{array}{l}.03 \\
(.11)\end{array}$ & $\begin{array}{l}.21 \\
(.16)\end{array}$ & $\begin{array}{l}.20 \\
(0.16)\end{array}$ \\
\hline$\rho$ & \multicolumn{2}{|c|}{$.752 * *(.17)$} & \multicolumn{2}{|c|}{$0.797 * *(.21)$} & \multicolumn{2}{|c|}{$0.763 * *(170.95)$} & & \\
\hline $\operatorname{Ln} L$ & -252 & & -253 & & -178 & & -86 & -92 \\
\hline
\end{tabular}

*** is at $1 \%$ significant level, $* *$ is at $5 \%$ and $*$ is at $10 \%$.

\section{Sensitivity Test}

A sub-sample is used to test the validity of empirical results for the original model, and then the entire sample is tested on different liner models again to compare the results with previous evidence obtained. Detailed robust test results are as below. 
(1) Sub-sample Testing

For this test, only a sub-sample for firms with the IGCQ is included and further divided into delisting and non-delisting, as a result, a total of 201 IGCQ firms are obtained. By applying the A, B, C, and D models to estimate variables, Table 6 shows no significant differences among the models.

Table 6. Sub-sample testing results of bivariate probit model

\begin{tabular}{|c|c|c|c|c|c|c|c|c|}
\hline Model & & A & & B & & $\mathrm{C}$ & $\mathrm{D}$ & $\mathrm{E}$ \\
\hline Variable & DELIST & SWITCH & DELIST & SWITCH & DELIST & SWITCH & DELIST & SWITCH \\
\hline CONSTANT & Г $3.53^{* * *}$ & $-1.44 * * *$ & $3.78 * *$ & -.415 & $3.07 * *$ & $-1.44 * *$ & $2.97^{* * *}$ & $-2.57 * *$ \\
\hline & $(1.21)$ & (.41) & (1.2) & (1.02) & (1.46) & $(.42)$ & (1.2) & $(.56)$ \\
\hline DELIST & & & & $1.41^{* *}$ & & & & \\
\hline & & & & $(.82)$ & & & & \\
\hline SWITCH & & & & & $1.06^{*}$ & & & \\
\hline & & & & & (.78) & & & \\
\hline IGCQY1 & & $1.9^{* * *}$ & & $1.71^{* * *}$ & & $1.95^{* * *}$ & & $2.65^{* * *}$ \\
\hline & & $(.41)$ & & $(.54)$ & & $(.42)$ & & $(.42)$ \\
\hline IGCQY2 & & & & & & & & $2.16^{* * *}$ \\
\hline & & & & & & & & $(.47)$ \\
\hline IGCQY3 & & & & & & & & 8.12 \\
\hline & & & & & & & & $\left(3.8 \times 10^{5}\right)$ \\
\hline AGE & .004 & $.027 * *$ & .004 & $.026^{* *}$ & $.001 *$ & $.026^{* *}$ & .003 & $.044^{* *}$ \\
\hline & $(.014)$ & $(.012)$ & $(.014)$ & (.009) & $(.015)$ & $(.012)$ & $(.001)$ & $(.016)$ \\
\hline LOSS & -.24 & & -.17 & & -.489 & & -.305 & \\
\hline & (.43) & & (.416) & & (.43) & & (.369) & \\
\hline B4 & .06 & $.64^{* *}$ & .086 & $.59 * *$ & .122 & $.664^{* * *}$ & .095 & $.426 * * *$ \\
\hline & $(.24)$ & $(.25)$ & $(.246)$ & $(.26)$ & $(.323)$ & $(.257)$ & $(.095)$ & (.325) \\
\hline SIZE & $-.16^{* *}$ & .001 & $-.186^{* *}$ & .001 & -.152 & .001 & $-.141 *$ & .001 \\
\hline & $(.08)$ & $(.002)$ & $(.082)$ & $(.002)$ & (.09) & $(.003)$ & $(.077)$ & $(.0001)$ \\
\hline FINANCE & -.05 & -.029 & -.003 & -.031 & .04 & -.117 & $.294 *$ & -.043 \\
\hline & $(.27)$ & $(.28)$ & (.269) & (.277) & $(.284)$ & $(.447)$ & $(.177)$ & $(.26)$ \\
\hline $\bar{\rho}$ & $.604 *(.18$ & & $0.626 *($. & & $0.614 *$ & 31) & & \\
\hline $\operatorname{Ln} L$ & -163 & & -162 & & -161 & & -86 & -45 \\
\hline
\end{tabular}

*** is at $1 \%$ significant level, $* *$ is at $5 \%$ and $*$ is at $10 \%$.

(2) Testing on Different Models

To check the robustness of the bivariate probit model, the $\mathrm{B}$ and $\mathrm{C}$ recursive simultaneous equations are tested and compared with the other three models. Table 7 is the result comparison for the five models' testing, including their estimated coefficients and degrees of fitness. 
Table 7. Different model testing results of sensitivity tests

\begin{tabular}{|c|c|c|c|c|c|c|c|c|}
\hline \multirow{2}{*}{$\begin{array}{c}\text { Model } \\
\text { Variable }\end{array}$} & \multicolumn{2}{|c|}{ SURE } & \multicolumn{2}{|r|}{ B } & \multicolumn{2}{|c|}{ C } & \multirow{2}{*}{$\begin{array}{l}\text { Probit } \\
\text { DELIST }\end{array}$} & \multirow{2}{*}{$\begin{array}{l}\text { Probit } \\
\text { SWITCH }\end{array}$} \\
\hline & DELIST & SWITCH & DELIST & SWITCH & DELIST & SWITCH & & \\
\hline \multirow[t]{2}{*}{ CONSTANT } & Г.089*** & $-.095 * * *$ & -4.08 & $-2.81 * *$ & -3.99 & $-3.45 * *$ & -177.4 & $-3.43 * * *$ \\
\hline & $(.026)$ & $(.026)$ & (92.07) & (.28) & (93.26) & $(.36)$ & $\left(1.9 \times 10^{5}\right)$ & (.35) \\
\hline \multirow[t]{2}{*}{ DELIST } & & $1.01^{* * *}$ & & & & $2.27 * *$ & & \\
\hline & & $\left(5.6 \times 10^{5}\right)$ & & & & $(.17)$ & & \\
\hline \multirow[t]{2}{*}{ SWITCH } & $.994 * * *$ & & $1.44^{* * *}$ & & & & $.355^{* *}$ & \\
\hline & $\left(5 \times 10^{5}\right)$ & & (.19) & & & & $(.615)$ & \\
\hline \multirow[t]{2}{*}{ IGCQ } & $1.2 \times 10^{-6}$ & & 5.73 & & 5.51 & & 181.3 & \\
\hline & $\left(6 \times 10^{-5}\right)$ & & (92.54) & & (93.44) & & $\left(1.9 \times 10^{5}\right)$ & \\
\hline \multirow[t]{2}{*}{ RGCQ } & $9.8 \times 10^{-8}$ & & -.25 & & -.20 & & -.25 & \\
\hline & $\left(4 \times 10^{-5}\right)$ & & $(.16)$ & & $(.22)$ & & $(.22)$ & \\
\hline \multirow[t]{2}{*}{ IGCQY1 } & & $-6.4 \times 10^{-11}$ & & $3.06^{* *}$ & & $1.66^{* *}$ & & $2.41^{* *}$ \\
\hline & & $\left(2.9 \times 10^{-7}\right)$ & & $(.34)$ & & $(.38)$ & & $(.36)$ \\
\hline \multirow[t]{2}{*}{ AGE } & .006 & .006 & .014 & $.026 * *$ & $.001^{*}$ & $.022 *$ & .026 & $.027 * *$ \\
\hline & $(.001)$ & $(.001)$ & $(.011)$ & $(.009)$ & $(.014)$ & $(.011)$ & (.011) & $(.009)$ \\
\hline \multirow[t]{2}{*}{ LOSS } & -.001 & & $-1.15^{* * *}$ & & -.33 & & -.31 & \\
\hline & $(.02)$ & & (.33) & & $(.47)$ & & $(.37)$ & \\
\hline \multirow[t]{2}{*}{ B4 } & .083 & $.084^{* * *}$ & .05 & .15 & .001 & .28 & .003 & $.32 * * *$ \\
\hline & $(.21)$ & $(.02)$ & $(.20)$ & $(.16)$ & $(.25)$ & (.19) & $(.23)$ & $(.24)$ \\
\hline \multirow[t]{2}{*}{ SIZE } & $-.001^{*}$ & .001 & .002 & .001 & -.001 & .001 & $.170^{* *}$ & .001 \\
\hline & $(.0012)$ & $(.0001)$ & (.058) & $(.004)$ & $(.03)$ & $(.029)$ & $(.081)$ & $(.001)$ \\
\hline \multirow[t]{2}{*}{ FINANCE } & -.09 & .08 & .20 & .08 & .42 & .03 & .3 & .14 \\
\hline & $(.54)$ & $(.05)$ & $(.18)$ & $(.05)$ & $(.16)$ & $(.11)$ & $(.40)$ & $(.48)$ \\
\hline$\rho$ & & & \multicolumn{2}{|c|}{$0.797 *(0.21)$} & \multicolumn{2}{|c|}{$0.763 * *(170)$} & & \\
\hline $\operatorname{Ln} L$ & -116 & -121 & \multicolumn{2}{|c|}{-253} & \multicolumn{2}{|c|}{-178} & -86 & -115 \\
\hline
\end{tabular}

*** is at $1 \%$ significant level, $* *$ is at $5 \%$ and $*$ is at $10 \%$.

The SURE model is applied by a linear SUR (linear seemingly unrelated) model, similar to the bivariate probit model. Same coefficient directions and significant levels in key variables are derived from the models of SURE, B, and C (the recursive simultaneous equations). In addition, if employed separately by the probit models, only the significant levels exert very small changes but the coefficient directions remain the same as those of model B and C in general. Therefore, according to these sensitivity tests, we conclude that the bivariate probit model is robust by applying different model estimation methods. Therefore, the empirical evidence from the bivariate probit model is highly valid and trustworthy.

\section{Conclusions}

When GAAS are followed, an IGCQ does not make a client's delisting its auditor's responsibility. The main purpose of this paper is not to discuss who should account for the 
delisting but to measure adverse impacts on the stock and audit market after the IGCQ issued, including delisting and auditor switching. However, if the stock and audit markets interact, delisting and auditor switching are themselves correlated. We investigated if delisting and auditor switching are subjected to unobservable factors simultaneously, in addition to the self-fulfilling prophecy effect in Taiwanese stock market when there is an IGCQ to precipitate client delisting. On the other hand, we also discussed if the demand for audit service would be affected by an IGCQ and if so, when auditor switching would occur.

We proved empirically there are unobserved interfering factors affecting client delisting and auditor switching after an IGCQ issued. While auditor switching influences client delisting, delisting itself also directly affects auditor switching, proving the two adverse effects by the IGCQ are not independent. Since delisting and auditor switching interact within the stock and audit market, conclusions based on the assumption that relevant markets function independently are biased. Moreover, we do not find evidence of the self-fulfilling prophecy effect in the Taiwanese stock market and other vital unobserved variables, because neither the IGCQ nor RGCQ has a significant impact on client delisting. However, we empirically prove that delisting significantly causes auditor switching to occur one year after an IGCQ is issued.

The main purpose of this study is to provide all related parties in the stock and audit market and regulatory agencies with useful information. For auditors, when clients are delisted and are likely to switch auditors afterward, CPA firms may face a reduction of audit engagements. In addition, clients associated with more audit risks should face higher risk premiums, or firms should transfer and consider risks in certain additional ways. Share investors should evaluate how the IGCQ may affect stock prices based on all relevant information. This study provides non-financial information about the possibility of auditor switching, a useful index for predicting future delisting of an IGCQ firm. For regulatory agencies, prior signals of financial hardships or unusual auditor switching should be used to prevent adverse effects on financial markets.

\section{References}

Addams, H., \& Davis, B. (1994). Privately held companies report reasons for selecting and switching auditors. CPA Journal, 64, 38-41.

Altman, E. (1968). Financial ratio, discriminate analysis and the prediction of corporate bankruptcy. Journal of Finance, 23(4), 589-609. http://dx.doi.org/10.1111/j.1540-6261.1968.tb00843.x

Anderson, K. (2011). The effects of hindsight bias on auditors' confidence in going-concern judgments and on the audit opinion decision. Journal of Business \& Economics Research, 9(9), 1-11.

Asthana, S. C., Balsam, S., \& Krishnan, J. (2010). Corporate governance, audit firm reputation, auditor switches, and client stock price reactions: The Anderson experience. International Journal of Auditing, 14(3), 274-293. http://dx.doi.org/10.1111/j.1099-1123.2010.00417.x 
Bruynseels, L., Knechel, W. R., \& Willekens, M. (2011). Auditor differentiation, mitigating management actions, and audit-reporting accuracy for distressed firms. Auditing, 30(1), 1-20. http://dx.doi.org/10.2308/aud.2011.30.1.1

Carcello, J. V., \& Vanstraelen, A. (2009). Rules rather than discretion in Audit standards: Going-concern opinions in Belgium. The Accounting Review, 84(5), 1395-1428. http://dx.doi.org/10.2308/accr.2009.84.5.1395

Cassell, C. A., Giroux, G. A., Myers, L. A., \& Omer, T. C. (2012). The effect of corporate governance on auditor-client realignments. Auditing, 31(2), 167-188. http://dx.doi.org/10.2308/ajpt-10240

Carver, L. (2012). The cost of liquidation. Risk, 25(4), 21-23.

Chang, H., Cheng, C. S., \& Reichelt, K. J. (2010). Market reaction to auditor switching from big 4 to third-tier small accounting firms. Auditing, 29(2), 83-114. http://dx.doi.org/10.2308/aud.2010.29.2.83

Charitou, A., Lambertides, N., \& Trigeorgis, L. (2007). Managerial discretion in distressed firms. The British Accounting Review, 39(4), 323-346. http://dx.doi.org/10.1016/j.bar.2007.08.003

Chen, K., \& Lee, J. (1993). Financial ratios and corporate endurance: A case of the oil and gas industry. Contemporary Accounting Research, 9(2), 667-694. http://dx.doi.org/10.1111/j.1911-3846.1993.tb00903.x

Chen, C., Su, X., \& Wu, X. (2010). Auditor changes following a big 4 merger with a local Chinese firm: A case study. Auditing, 29(1), 41-72. http://dx.doi.org/10.2308/aud.2010.29.1.41

Citron, D. B., \& Taffler, R. J. (1992). The audit report under going-concern uncertainties: An empirical analysis. Accounting and Business Research, 22, 337-345. http://dx.doi.org/10.1080/00014788.1992.9729449

Citron, D. B., \& Taffler, R. J. (2001). Ethical behavior in the U.K. audit profession: The case of the self-fulfilling prophecy under going-concern uncertainties. Journal of Business Ethics, 29(4), 353-363. http://dx.doi.org/10.1023/A:1010752209148

DeFond, M, L. (1992). The association between changes in client firms: agency costs and auditor switching. Auditing, Spring, 16-31.

Feng, N. C. (2013). Fiscal year-end and non-lateral auditor switches. Journal of Applied Accounting Research, 14(3), 268-292. http://dx.doi.org/10.1108/JAAR-05-2012-0041

Franken, S. (2004). Creditor- and debtor-oriented corporate bankruptcy regimes revisited. European Business Organization Law Review, 5(4), 645-676. http://dx.doi.org/10.1017/S1566752904006457

Franks, J., Nyborg, K., \& Torous, W. (1996). A comparison of US, UK, and German insolvency codes. Financial Management, 25(3), 86-101. http://dx.doi.org/10.2307/3665810 
George, C., Spiceland, J., \& George, S. (1996). A longitudinal study of the going-concern audit decision and survival time. Advances in Quantitative Analysis of Finance and Accounting, 4, 77-103.

Greene, W. H. (2003). Econometric Analysis., New Jersey: Prentice Hall.

Guiral, A., Ruiz, E., \& Rodgers, W. (2011). To what extent are auditors' attitudes toward the evidence influenced by the self-fulfilling prophecy? Auditing, 30(1), 173-190. http://dx.doi.org/10.2308/aud.2011.30.1.173

Haskins, M. E., \& Williams, D. D. (1990). A contingent model of intra-big 8 auditor changes. Auditing, 9, 55-74.

Islam, M. (2013). Auditing in the $21^{\text {st }}$ century: Has self-regulation failed? Journal of Modern Accounting and Auditing, 9(8), 1059-1069.

Krishnan, J. (1994). Auditor switching and conservatism. The Accounting Review, January, 200-215.

Krishnan, J., \& Stephens, R. (1995). Evidence on opinion shopping from audit opinion conservatism. Journal of Accounting and Public Policy, 14, 179-201. http://dx.doi.org/10.1016/0278-4254(95)00020-F

Kuruppu, N., Laswad, F., \& Oye assessing lere, P. (2003). The efficacy of liquidation and bankrupt prediction models for going concern. Managerial Auditing Journal, 18, 577-589. http://dx.doi.org/10.1108/02686900310482713

Lennox, C. (2000). Do companies successfully engage in opinion-shopping? Evidence from the UK. Journal of Accounting and Economics, 29, 321-337. http://dx.doi.org/10.1016/S0165-4101(00)00025-2

Lopez, D. M., \& Peters, G. F. (2011). Auditor workload compression and busy season auditor switching. Accounting Horizons, 25(2), 357-380. DOI: 10.2308/a ch-10026

Louwers, T. J., Messina, F. M., \& Richard, M. D. (1999). The auditor's going-concern disclosure as a self-fulfilling prophecy: A discrete-time survival analysis. Decision Sciences, 30(3), 805-823. http://dx.doi.org/10.1111/j.1540-5915.1999.tb00907.x

Maddala, G. (1983). Limited dependent and qualitative variables in Econometrics. New York: Cambridge University Press. http://dx.doi.org/10.1017/CBO9780511810176

Menon, K., \& Schwartz, K. B. (1985). Auditor switches by failing firms. The Accounting Review, April, 248-261.

Menon, K., \& Williams, D. (1991). Auditor credibility and initial public offering. The Accounting Review, 66(2), 313-332.

Minnis, M. (2011). The value of financial statement verification in debt financing: evidence from private U.S. firms. Journal of Accounting Research, 49(2), 457-506. http://dx.doi.org/10.1111/j.1475-679X.2011.00411.x 


\section{Macrothink}

Asian Journal of Finance \& Accounting

ISSN 1946-052X

2014, Vol. 6, No. 1

Mutchler, J. F. (1984). Auditors' perceptions of the going-concern opinion decision. Auditing, 3, 17-30.

Nogler, G. (1995). The resolution of auditor going-concern opinions. Auditing, 14(2), 54-73.

Schwartz, K., \& Soo, B. (1996). Evidence of regulatory noncompliance with SEC disclosure rules on auditor changes. The Accounting Review, 71(4), 555-573.

Smolarski, J., Wilner, N., \& Yang, W. (2011). The use of financial information by private equity funds in evaluating new investments. Review of Accounting and Finance, 10(1), 46-68. http://dx.doi.org/10.1108/14757701111113811

Stunda, R. (2012). Auditor switches in a post-sox environment, does the change in auditor mean a change in stock price? Journal of Business and Behavior Science, 24(3), 58-67.

Stunda, R., \& Pacini, C. (2013). The shareholder wealth effects of auditor changes and auditor opinions: Does a difference exist in a pre-SOX versus post-SOX environment? Academy of Accounting and Financial Studies Journal, 17(4), 29-40.

Thevenot, M., \& Hall, L. (2011). Adverse internal control over financial reporting opinions and auditor dismissals/resignations. Academy of Accounting and Financial Studies Journal, 15(4), 41-60.

Tucker, R., \& Matsumura, E. (1998). Going-concern judgments: An economic perspective. Behavioral Research in Accounting, 10, 179-218.

Tucker, R., Matsumura, E. M., \& Subramanyam, K. R. (2003). Going-concern judgements: An experimental test of the self-fulfilling prophecy and forecast accuracy. Journal of $\begin{array}{llll}\text { Accounting and Public } & \text { 401-432. }\end{array}$ http://dx.doi.org/10.1016/j.jaccpubpol.2003.08.002

Vanstraelen, A. (2003). Going-concern opinions, auditor switching, and the self-fulfilling prophecy effect examined in the regulatory context of Belgium. Journal of Accounting, Auditing and Finance, 18(2), 231-253.

Yanan, Z., Wen, C., \& Jinzheng, R. (2013). Auditor switching by corporate governance: Empirical analysis from the listed company in China. Journal of Modern Accounting and Auditing, 9(2), 230-238. 